\title{
AGE, GROWTH, AND DIET OF AXILLARY SEABREAM, PAGELLUS ACARNE (ACTINOPTERYGII: PERCIFORMES: SPARIDAE), IN THE CENTRAL AEGEAN SEA
}

\author{
Dilek İLHAN* \\ Faculty of Fisheries, Ege University, Bornova-İzmir, Turkey
}

İlhan D. 2018. Age, growth, and diet of axillary seabream, Pagellus acarne (Actinopterygii: Perciformes: Sparidae), in the central Aegean Sea. Acta Ichthyol. Piscat. 48 (4): 329-339.

\begin{abstract}
Background. The knowledge of the age, growth, and feeding ecology of fish species is essential for conservation, monitoring, and management activities required for the sustainable use of fish stocks. The objective of this work was to describe the growth and feeding of Pagellus acarne from the Gulf of İzmir, central Aegean Sea. The information provided in this study contributes to the knowledge which is for sustainable management applications. Material and methods. The study was carried out to investigate the growth and feeding characteristics of axillary seabream, Pagellus acarne (Risso, 1827), in the Gulf of İzmir, the central Aegean Sea, from commercial trawl fishery between October 2012 and September 2013. Age and growth were determined by annuli counts of sagittal otoliths. Length-weight relation and the von Bertalanffy equation were used to evaluate the fish growth. Percentages by number, weight, and frequency of each food category were determined, and the index of relative importance (\%IRI) was calculated to define the main food categories. A similarity of diet was also examined according to a season and fish size.

Results. A total of 2036 specimens' were analysed. The lengths ranged from 7.5 to $22.0 \mathrm{~cm}$ and the weights ranged from 4.55 to $138.45 \mathrm{~g}$. For the age determination, a total of 547 left sagittal otoliths were extracted. The age ranged from 0 to 4 years. Von Bertalanffy growth parameters were determined from mean lengths of age groups and the following parameters were obtained: $L_{\infty}=27.75 \mathrm{~cm}, 22.45 \mathrm{~cm}$, and $25.61 \mathrm{~cm} ; k=0.201$ year $^{-1}$, 0.341 year $^{-1}$, and 0.249 year $^{-1} ; t_{0}=-2.347$ years, -1.554 years, and -1.938 years; $\phi^{\prime}=2.190,2.235$, and 2.213 for females, males, and both sexes combined, respectively. Stomach content analyses revealed that Pagellus acarne was defined as a carnivorous, euryphagous, and zooplanktivorous species, and Copepoda (Harpacticoida), Polychaeta, and Decapoda were the most important prey groups.

Conclusion. This study provides the age, growth, and the first detailed information on the feeding composition of axillary seabream from the central Aegean Sea. Results reported in this work will contribute to management strategies and regulations needed for sustainable conservation for the remaining stocks of the species.
\end{abstract}

Keywords: Pagellus acarne, LWR, growth parameters, stomach content, similarity index, central Aegean Sea

\section{INTRODUCTION}

The axillary seabream, Pagellus acarne (Risso, 1827), is a member of the family Sparidae. It is widely distributed along the northern and eastern Atlantic coasts from Norway to Senegal, around the Macaronesian Islands, and in the Mediterranean Sea. While the adults inhabit various types of bottoms, especially seagrass beds and sand down to the depth of $500 \mathrm{~m}$, usually between $40 \mathrm{~m}$ and $100 \mathrm{~m}$, the juveniles are found closer to the shore (Froese and Pauly 2018).

Pagellus acarne is of high commercial importance and is targeted by demersal fleets operating along the eastern Atlantic coasts and the Mediterranean Sea (Russell et al. 2014).
Although there were many studies on its growth and reproduction (Phân and Kompowski 1972, Andaloro 1982, Domanevskaya and Patokina 1985, Santos et al. 1995, Greco et al. 1995, Stergiou et al. 1997, Tosunoğlu et al. 1997, Pajuelo and Lorenzo 2000, Coelho et al. 2005, Abecasis et al. 2008, Velasco et al. 2011, Dragičević et al. 2012, Soykan et al. 2015), information regarding its feeding is scarce and variable in its extent (Rizkalla et al. 1999, Morato et al. 2001, Fehri-Bedoui et al. 2009, Fanelli et al. 2011, Dragičević et al. 2015).

The aim of the presently reported study was to investigate some aspects of the biology of Pagellus acarne in the central Aegean Sea, focusing on age and growth. The study also provides the first detailed information on 
the diet of the species, based on different size groups and seasons, using qualitative and quantitative analyses from the central Aegean Sea.

\section{MATERIAL AND METHODS}

Specimens of the axillary seabream, Pagellus acarne, were collected seasonally from commercial trawlers between October 2012 and September 2013 from the Gulf of İzmir, central Aegean Sea (Fig. 1). A total of 2036 individuals of $P$. acarne were obtained. All specimens were measured to the nearest $\mathrm{mm}$ and weighed to the nearest $g$ (wet weight). The specimens were dissected for macroscopic determination of sex. The sex ratio was calculated for the entire study period and its significance was tested by Chi-square $\left(\chi^{2}\right)$ test (Nikolsky 1963).

The commonly used length-weight relation

$$
W=a \cdot L^{b}
$$

was applied, where $W$ is the weight [g], $L$ is the total length $[\mathrm{cm}] a$ is the intercept of the regression curve and $b$ is the regression coefficient (slope) (Sparre and Venema 1992). The hypothesis of isometric growth (Ricker 1975) was tested by Student's $t$-test.

All sagittal otoliths were dissected, cleaned of their excess tissues, and stored dry inside microplates. The otoliths were examined after being transferred to $70 \%$ alcohol, then they were immersed in glycerine under reflected light against a dark background with the acoustic sulcus facing downwards. The $20 \times$ magnification of an Olympus SZ61 binocular microscope was used. To minimize reading errors, the number of opaque rings outside the nucleus was evaluated by two readers. For all otoliths, the date of capture was recorded and known to the readers before reading, together with the date of hatching. The difference between the date of hatching and capture helped readers to calculate the annual fraction elapsed since the hatching date, which was added to the number of complete hyaline zones read in the otoliths (Gordoa and Moli 1997). Formations of otolith opaque zone were assumed to relate to spawning activities, water temperature, or food supply (Beckman and Wilson 1995). In the presently reported results, the formation of opaque zones was observed in the period from September to January with a peak in December, and these months coincided with the spawning season which was also observed in axillary seabream captured off north-west Africa during November and March (Phân and Kompowski 1972), and in the Canary Islands during September and March (Pajuelo and Lorenzo 2000). If the readings did not coincide between the readers, the otolith was rejected (Fig. 2).

For the estimation of individual growth rate, the von Bertalanffy growth equation for length (Sparre and Venema 1992) was used

$$
\left.L_{t}=L_{\infty}\left[1-e^{-k(t-t} 0\right)\right]
$$

where $L_{t}$ is the total length at age $t, L_{\infty}$ is the asymptotic total length, $k$ is the growth curvature parameter, and $t_{0}$ is the theoretical age when the fish would have been at zero total length (Sparre and Venema 1992).

The growth performance index phi-prime $\left(\varphi^{\prime}\right)$ was estimated to compare the growth parameters with the previous studies. This index was calculated by the equation (Munro and Pauly 1983)

$$
\varphi^{\prime}=\log k+2 \log L_{\infty}
$$

The longevity was calculated using the Taylor's (1958) equation

$$
t_{\max }=3 k^{-1}
$$

where $t_{\max }$ is the longevity (maximum reachable age).

The fish stomachs were removed immediately after the capture and were stored in $4 \%$ buffered formalin solution until the contents were analysed. In the laboratory,

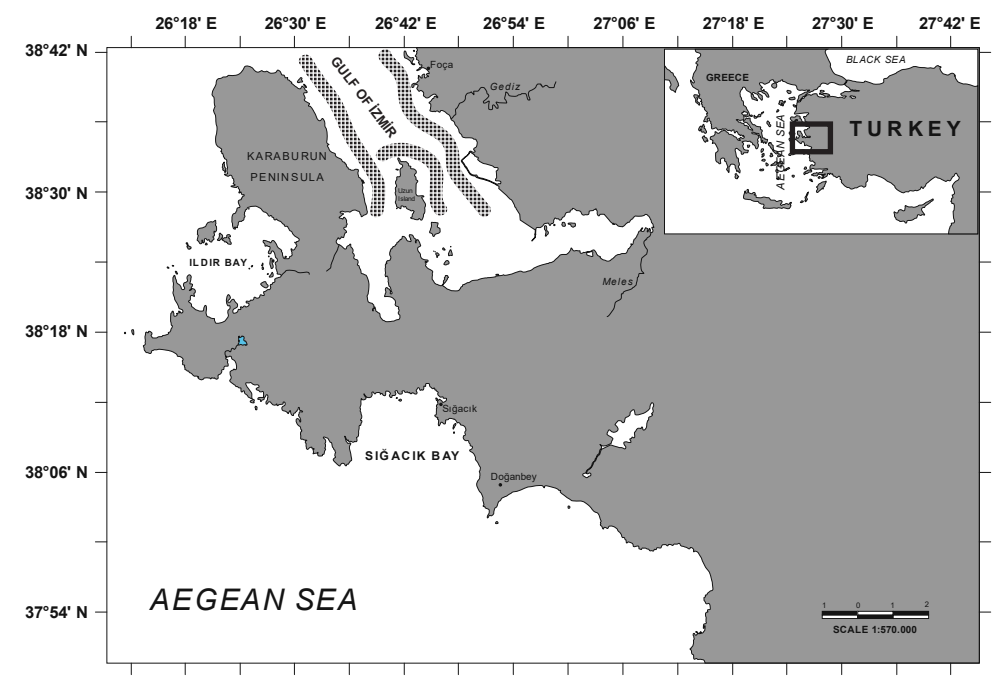

Fig. 1. The sampling area of Pagellus acarne between October 2012 and September 2013 
the stomach contents were assigned to the group or species level with a SZX7 Olympus stereo microscope. Once counted, the individuals of the same species were weighed together (wet weight to the nearest $0.0001 \mathrm{~g}$ ) after the moisture was removed by blotting paper. The identification of digested copepods was done from body part by following the methods of Rose (1933) and Wells (2007).

For a quantitative description of the diet, the Hyslop (1980) equations were used; the numerical index $(\% N)$; the gravimetric index $(\% W)$, and frequency of occurrence $(\% F)$. Main food items were determined using the index of relative importance (IRI) (Pinkas et al. 1971)

$$
\mathrm{IRI}=\% F \cdot(\% N+\% W)
$$

The index of relative importance (IRI) was calculated and expressed as a percentage

$$
\% \mathrm{IRI}=100 \cdot \mathrm{IRI} \cdot(\Sigma \mathrm{IRI})^{-1}
$$

\%IRI was computed in order to determine ratios of food groups in the stomach to overall food groups. Subsequently, food items were grouped into categories of preference using the method proposed by Morato-Gomes (unpublished*). The categories were defined as follows:
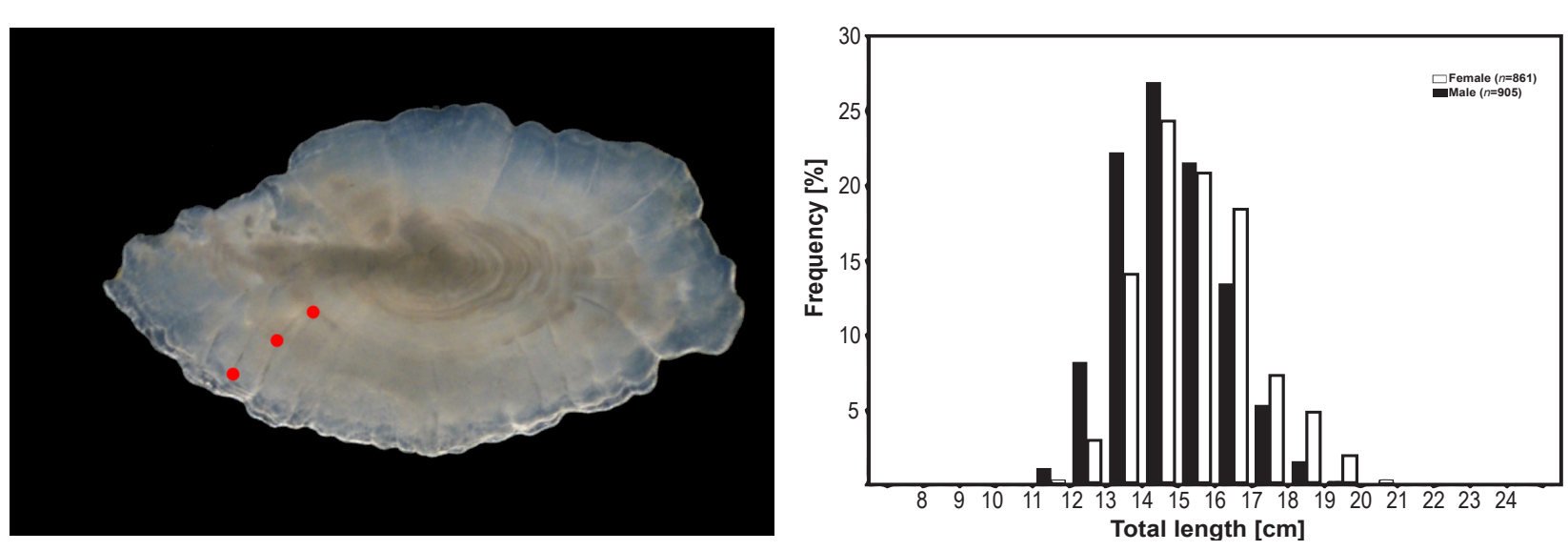

Fig. 2. Sagittal otolith from a 3 -year-old male ( $\mathrm{TL}=17.2$ cm) Pagellus acarne collected in December 2012 from the central Aegean Sea
IRI $\geq 30 \times(0.15 \times \Sigma \% F) \ldots \ldots \ldots \ldots . .$. main important prey $(\mathrm{MIP})$ $30 \times(0.15 \times \Sigma \% F)>$ IRI $>10 \times(0.05 \times \Sigma \% F)$

$\mathrm{IRI} \leq 10 \times(0.05 \times \Sigma \% F)$ secondary prey $(\mathrm{SP})$

Seasonal and length group differences in the diet composition were determined by the Bray-Curtis similarity index, using percentage numerical data (Washington 1984).

\section{RESULTS}

In this study, we examined a total of 2036 individuals of the axillary seabream, Pagellus acarne, of which 905 (45\%) were males, 861 (42\%) females, and 270 $(13 \%)$ were not identified (33 of them were immature individuals). The overall sex ratio (female $\div$ male) was calculated as $1 \div 1.05$. According to the Chi-square test $\left(\chi^{2}\right)$ there were no significant differences in the female : male ratio of the fish sampled $\left(\chi^{2}=1.096<\chi^{2}, t_{0.05}=3.84\right.$, $P>0.05)$.

The total length and weight of $P$. acarne ranged from 7.5 to $22.0 \mathrm{~cm}$ and from 4.55 to $138.45 \mathrm{~g}$, respectively. The total length of females ranged from 11.9 to $22.0 \mathrm{~cm}$ (40.53 to $138.45 \mathrm{~g}$ ) and males ranged from 11.1 to $19.5 \mathrm{~cm}$ (19.62 g to $92.16 \mathrm{~g}$ ) (Fig. 3). The majority of fish were between $14.0-15.0 \mathrm{~cm} \mathrm{TL}$, accounting for $44 \%$ of all samples.

Fig. 3. Length frequency distribution of Pagellus acarne collected from the central Aegean Sea between October 2012 and September 2013

\begin{tabular}{|c|c|c|c|c|c|c|c|c|c|}
\hline Sex & $n$ & $\mathrm{TL}[\mathrm{cm}]$ & TW $[\mathrm{g}]$ & $a$ & $b$ & $\operatorname{SE}(b)$ & $R$ & $t$-test & GT \\
\hline q & 861 & $11.9-22.0$ & $20.53-138.45$ & 0.0109 & 3.066 & 0.0261 & 0.970 & $2.513^{\mathrm{a}}$ & $\mathrm{A}+$ \\
\hline 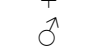 & 905 & $11.1-19.5$ & $19.62-92.16$ & 0.0153 & 2.943 & 0.0289 & 0.960 & -1.975 & A- \\
\hline$q+\hat{0}$ & 2036 & $7.5-22.0$ & $4.55-138.45$ & 0.0089 & 3.142 & 0.0132 & 0.983 & 10.759 & $\mathrm{~A}^{+}$ \\
\hline
\end{tabular}

Parameters of length-weight relation of Pagellus acarne from the central Aegean Sea

$q=$ female, $\hat{\delta}=$ male,$q+\hat{\delta}=$ females + males (including unsexed specimens), $n=$ number of specimens studied, $\mathrm{TL}=$ total length, $\mathrm{TW}=$ total weight, $a=$ intercept, $b=$ slope, $\mathrm{SE}(\mathrm{b})=$ standard error of the slope, $R=$ coefficient of determination, $\mathrm{GT}=$ growth type; $\mathrm{A}+=$ positive allometric, A- = negative allometric, $\mathrm{I}=$ isometric $^{\mathrm{a}}=t$-test, $t<t_{0.05, n>200}=1.65^{\circ}$

"Morato-Gomes T. 1995. Ecologia alimentar de Serranus atricauda (Günther, 1874) dos Açores. [Food ecology of Serranus atrica$u d a$ (Günther, 1874) of the Azores.] "Licenciatura” Thesis, Universidade do Algarve, Faro, Portugal. [In Portuguese.] 
Length-weight relation parameters for females, males and all specimens are given in Table 1 . Value of the exponent $b$ was $3.066(R=0.970)$ for females and 2.943 $(R=0.960)$ for males. In terms of growth type, these results revealed negative allometry for males and positive allometry for females and combined sexes ( $t$-test, $P>$ 0.05).

A total of 547 otoliths were used for the age estimating and 215 of those were females, 228 males, and 104 sexually unidentified individuals (33 of them immature). Age structure of $P$. acarne ranged from 0 to IV years in the study area for all individuals. All of those at 0 age class represented immature fish. Our results indicate that I and II-year old fish were dominant in the population. The longevity $\left(t_{\max }\right)$ for pooled sexes was found to be 12.05 years (Table 2).

The calculated von Bertalanffy growth parameters and growth performance index values were given in Table 3 .

Stomach investigation of $206 P$. acarne specimens showed that $183(88.8 \%)$ stomachs were full and 23 $(11.2 \%)$ of stomachs were empty. Considering seasons, a high number of empty stomachs was observed in summer (22.9\%), which was followed by spring (17.6\%).

Samples were divided into three main length groups such as: less than $14.0 \mathrm{~cm}, 14.0-18.0 \mathrm{~cm}$, and more than $18.0 \mathrm{~cm}$ (Table 4).

Table 2

The von Bertalanffy growth parameters for Pagellus acarne from the central Aegean Sea

\begin{tabular}{cccccc}
\hline Sex & $n$ & $k$ & $t_{0}$ & $L_{\infty}$ & $\varphi^{\prime}$ \\
\hline$\varnothing$ & 215 & 0.201 & -2.347 & 27.75 & 2.190 \\
0 & 228 & 0.341 & -1.554 & 22.45 & 2.235 \\
$q+\hat{o}$ & 547 & 0.249 & -1.938 & 25.61 & 2.213 \\
\hline
\end{tabular}

$n=$ number of specimens studied, $k=$ growth rate, $t_{0}=$ hypothetic age at zero length, $L_{\infty}=$ asymptotic mean length, $\varphi^{\prime}=$ growth performance index value.
With regard to the relative importance (\%IRI) it has been observed that the most important food items were Copepoda (49.98\% and 46.71\%) and Polychaeta (13.42\% and $15.73 \%$ ), respectively for the first and the second group. The diet of individuals bigger than $18.0 \mathrm{~cm}$ consisted of Polychaeta (27.94\%), Mysidacea (16.13\%), Amphipoda (12.20\%), fish (Actinopterygii) (10.53\%), and Decapoda $(10.03 \%)$. Copepoda constituted a rather minor part of the diet in the largest length group (6.21\%).

Regardless of the fish size, Copepoda was observed to have appeared in the diet throughout the year (Table 5) and emerged especially as predominant in summer $(66.53 \%)$ and spring $(41.88 \%)$ but rare in autumn $(10.93 \%)$ and winter $(11.46 \%)$ in terms of relative importance (\%IRI). Polychaetes generally prevailed during spring (35.43\%) but they were less consumed in autumn (18.76\%), winter $(11.86 \%)$, and summer (9.63\%). Decapods were generally abundant from autumn (26.48\%) until winter (12.79\%) whereas Amphipoda dominated in the diet in winter $(23.39 \%)$. The role of mysids gradually increased from spring $(1.77 \%)$ to autumn (13.44\%). Bivalvia were mostly found in winter $(17.42 \%)$, but they formed a minor part of the diet in spring $(0.22 \%)$.

According to the Bray-Curtis similarity index, the diet composition of axillary seabream was very similar among seasons. The dendrogram (Fig 4) showed a high percentage of similarity $(81.33 \%)$ between spring and summer, and also $(80.74 \%)$ autumn and winter. The variation in diet composition for length class (fish size) was also visualised in this dendrogram (Fig 4), which showed that the diet of the $14.0-18.0 \mathrm{~cm}$ class was slightly different from the others (similarity $76.78 \%$ ).

Harpacticoid copepods (Copepoda) were found to be the most significant prey group (MIP) in the diet for the first $(<14.0 \mathrm{~cm})$ and the second $(14.0-18.0 \mathrm{~cm})$ length groups while Polychaeta was the most significant prey group for the third $(>18.0 \mathrm{~cm})$ length group, in the study area.

Table 3

Distribution of individual total lengths of axillary seabream, Pagellus acarne, males, females, and all specimens combined from the central Aegean Sea, obtained from direct otolith readings

\begin{tabular}{ccccccc}
\hline Sex & Age group & Total length $[\mathrm{cm}]$ & Mean \pm CI $[\mathrm{cm}]$ & $n$ & SD & SE \\
\hline+ & I & $11.9-15.5$ & $13.60 \pm 0.198$ & 70 & 0.828 & 0.099 \\
& II & $14.9-17.1$ & $16.19 \pm 0.123$ & 74 & 0.528 & 0.061 \\
& III & $16.8-20.6$ & $18.28 \pm 0.184$ & 65 & 0.741 & 0.092 \\
& IV & $19.1-22.0$ & $20.02 \pm 1.005$ & 6 & 1.006 & 0.411 \\
& I & $11.1-15.3$ & $13.05 \pm 0.175$ & 95 & 0.858 & 0.088 \\
& II & $13.5-18.5$ & $15.76 \pm 0.275$ & 87 & 1.290 & 0.138 \\
$+\infty$ & III & $17.0-19.5$ & $17.78 \pm 0.149$ & 42 & 0.476 & 0.074 \\
& IV & $18.5-19.5$ & $19.10 \pm 0.546$ & 4 & 0.394 & 0.197 \\
& 0 & $7.5-10.7$ & $9.99 \pm 0.129$ & 94 & 0.629 & 0.065 \\
& I & $10.7-15.5$ & $13.29 \pm 0.137$ & 165 & 0.888 & 0.069 \\
& II & $13.5-18.5$ & $15.96 \pm 0.162$ & 161 & 1.037 & 0.082 \\
& III & $16.8-19.6$ & $18.23 \pm 0.155$ & 117 & 0.844 & 0.078 \\
\hline
\end{tabular}

$\mathrm{CI}=$ confidence interval, $n=$ number of specimens studied, $\mathrm{SD}=$ standard deviation, $\mathrm{SE}=$ standard error of the mean. 
When we examined the diet in terms of seasons, to be as much variable and we found that the sequence harpacticoid copepods were the most important prey of their abundance changed by both seasons and length group for spring and summer seasons, Decapoda was so groups. In addition, occasional prey groups (OP) were rare for autumn. Secondary prey groups (SP) were determined and variable, according to seasons and fish size (Table 6).

Table 4

Diet composition of axillary seabream, Pagellus acarne, in the central Aegean Sea by length classes

\begin{tabular}{|c|c|c|c|c|c|c|c|c|c|c|c|c|}
\hline \multirow{3}{*}{ Species or higher taxa } & \multicolumn{12}{|c|}{ Length class } \\
\hline & \multicolumn{4}{|c|}{$<14.0 \mathrm{~cm}(n=34)$} & \multicolumn{4}{|c|}{$14.0-18.0 \mathrm{~cm}(n=125)$} & \multicolumn{4}{|c|}{$>18.0 \mathrm{~cm}(n=43)$} \\
\hline & $\% N$ & $\% W$ & $\% F$ & $\%$ IRI & $\% N$ & $\% W$ & $\% F$ & $\%$ IRI & $\% N$ & $\% W$ & $\% F$ & $\%$ IRI \\
\hline Siphonophora & & & & & 0.02 & 0.05 & 0.93 & 0.01 & & & & \\
\hline Polychaeta & 7.86 & 9.38 & 70.97 & 13.42 & 8.73 & 14.57 & 51.40 & 15.73 & 22.50 & 18.97 & 11.20 & 27.94 \\
\hline Lumbrineris sp. & & & & & 0.05 & 0.10 & 1.87 & 0.01 & & & & \\
\hline Ostracoda & 9.07 & 0.95 & 41.94 & 4.63 & 11.70 & 1.72 & 40.19 & 7.03 & 3.55 & 0.26 & 3.47 & 0.80 \\
\hline Copepoda & 50.40 & 11.40 & 77.42 & 49.98 & 45.36 & 13.51 & 75.70 & 46.71 & 9.24 & 1.36 & 60.00 & 6.21 \\
\hline Calanoida & 1.09 & 0.04 & 19.35 & 0.24 & 0.77 & 0.04 & 10.28 & 0.11 & & & & \\
\hline Nannocalanus minor & & & & & 0.07 & 0.02 & 2.80 & 0.01 & 0.09 & 0.01 & 0.39 & 0.01 \\
\hline Pseudodiaptomus sp. & & & & & 0.69 & 0.41 & 6.54 & 0.09 & & & & \\
\hline Temora stylifera & 0.12 & 0.02 & 3.23 & 0.01 & 11.13 & 2.51 & 13.08 & 2.11 & 1.96 & 0.22 & 0.77 & 0.10 \\
\hline Centropages typicus & & & & & 0.07 & 0.01 & 2.80 & 0.01 & & & & \\
\hline Candacia armata & & & & & & & & & 0.09 & 0.03 & 0.39 & 0.01 \\
\hline Pseudocyclopia sp. & & & & & 0.02 & 0.01 & 0.93 & 0.01 & & & & \\
\hline Cyclopoida & 1.81 & 0.25 & 22.58 & 0.51 & 1.01 & 0.20 & 14.95 & 0.21 & 0.75 & 0.07 & 1.54 & 0.08 \\
\hline Corycaeus spp. & 0.12 & 0.01 & 3.23 & 0.01 & 0.10 & 0.02 & 0.93 & 0.01 & 0.28 & 0.02 & 1.16 & 0.02 \\
\hline Oncaea media & & & & & 0.05 & 0.01 & 0.93 & 0.01 & & & & \\
\hline Oncaea venusta & & & & & 0.02 & 0.01 & 0.93 & 0.01 & & & & \\
\hline Ditrichocorycaeus brehmi & & & & & 0.02 & 0.01 & 0.93 & 0.01 & & & & \\
\hline Harpacticoida & 47.28 & 11.07 & 74.19 & 47.66 & 31.36 & 10.24 & 58.88 & 30.02 & 6.07 & 1.00 & 8.88 & 3.74 \\
\hline Euterpina acutifrons & & & & & 0.02 & 0.005 & 0.93 & 0.01 & & & & \\
\hline Cirripedia larvae & 0.73 & 1.20 & 6.45 & 0.14 & 0.30 & 0.68 & 4.67 & 0.06 & 0.09 & 0.11 & 0.39 & 0.01 \\
\hline Mysidacea & 2.42 & 0.96 & 35.48 & 1.32 & 3.04 & 1.68 & 43.93 & 2.23 & 17.55 & 4.92 & 11.97 & 16.13 \\
\hline Isopoda & 1.57 & 0.38 & 19.35 & 0.42 & 0.77 & 0.26 & 14.02 & 0.19 & 2.99 & 0.51 & 6.18 & 1.30 \\
\hline Amphipoda & 10.88 & 2.10 & 48.39 & 6.92 & 6.88 & 1.85 & 50.47 & 5.54 & 14.01 & 1.91 & 12.74 & 12.20 \\
\hline Decapoda & 2.06 & 15.72 & 25.81 & 5.05 & 2.13 & 22.70 & 40.19 & 12.97 & 4.02 & 19.32 & 7.34 & 10.03 \\
\hline Tanaidacea & 6.53 & 7.33 & 41.94 & 6.40 & 4.18 & 6.55 & 28.97 & 4.02 & 1.12 & 0.89 & 3.09 & 0.37 \\
\hline Pteropoda & & & & & 0.07 & 0.01 & 0.93 & 0.01 & & & & \\
\hline Cumacea & 0.85 & 1.31 & 19.35 & 0.46 & 0.77 & 1.65 & 17.76 & 0.34 & 0.28 & 0.31 & 1.16 & 0.04 \\
\hline Brachyura larvae & 0.60 & 10.88 & 16.13 & 2.04 & 0.30 & 0.00 & 7.48 & 0.57 & 0.09 & 1.19 & 0.39 & 0.03 \\
\hline Gastropoda & 0.36 & 0.51 & 16.13 & 0.03 & 0.87 & 7.45 & 15.89 & 0.51 & 0.75 & 0.74 & 2.32 & 0.21 \\
\hline Bivalvia & 2.90 & 0.56 & 3.23 & 0.86 & 8.36 & 1.68 & 42.06 & 5.41 & 17.74 & 2.41 & 8.11 & 9.83 \\
\hline Chaetognatha & 0.12 & 0.13 & 3.23 & 0.01 & & & & & & & & \\
\hline Sagitta sp. & & & & & 0.15 & 0.07 & 5.61 & 0.01 & 1.03 & 0.36 & 8.89 & 0.12 \\
\hline Cladocera & 0.60 & 0.10 & 3.23 & 0.05 & & & & & & & & \\
\hline Penilia avirostris & & & & & 3.83 & 0.84 & 5.61 & 6.31 & & & & \\
\hline Stomatopoda & 0.24 & 8.60 & 6.45 & 0.63 & & & & & & & & \\
\hline Squilla mantis & & & & & & & & & 0.09 & 2.35 & 2.22 & 0.06 \\
\hline \multicolumn{13}{|l|}{ Pycnogonida } \\
\hline Achelia vulgaris & & & & & 0.19 & 0.10 & 4.44 & 0.02 & & & & \\
\hline Anoplodactylus petiolatus & & & & & & & & & 0.10 & 0.25 & 2.80 & 0.04 \\
\hline Echinodermata & 1.33 & 9.03 & 35.48 & 4.05 & 1.09 & 10.33 & 35.51 & 4.03 & 2.33 & 11.19 & 37.78 & 6.25 \\
\hline Actinopterygii & 1.09 & 19.45 & 35.48 & 5.11 & 0.47 & 10.31 & 14.02 & 2.13 & 1.40 & 33.26 & 5.02 & 10.53 \\
\hline Actinopterygii eggs & 0.36 & 0.02 & 22.58 & 0.04 & 0.74 & 11.72 & 9.35 & 0.10 & 1.03 & 0.04 & 2.32 & 0.15 \\
\hline Algae & 0.090 & 0.02 & 6.452 & 0.01 & & 0.10 & 0.08 & 0.15 & 0.01 & & & \\
\hline
\end{tabular}

$n=$ number of stomachs examined, $\% N=$ the numerical index, $\% W=$ the gravimetric index, $\% F=$ frequency of occurrence, $\%$ IRI $=$ the index of relative importance. The values were calculated separately for the higher taxa (bold) and for individual species representing them to show their importance in the diet and not be included in the sum of the Table. 


\section{DISCUSSION}

Age estimation is one of the most important topics in fisheries science for determination of growth. The otolith is one of the most suitable options for age determination of tropical and subtropical marine fishes (Hilborn and Walters 1992, Green et al. 2009). In this study, the maximum determined fish age was 4 years. Soykan et al. (2015) stated the maximum age of Pagellus acarne was 6 years, which

Table 5

Diet composition of axillary seabream, Pagellus acarne, in the central Aegean Sea by seasons

\begin{tabular}{|c|c|c|c|c|c|c|c|c|c|c|c|c|c|c|c|c|}
\hline \multirow[b]{2}{*}{ Species } & \multicolumn{4}{|c|}{ Spring $(n=51)$} & \multicolumn{4}{|c|}{ Summer $(n=48)$} & \multicolumn{4}{|c|}{ Autumn $(n=52)$} & \multicolumn{4}{|c|}{ Winter $(n=55)$} \\
\hline & $\% N$ & $\% W$ & $\% F$ & $\%$ IRI & $\% N$ & $\% W$ & $\% F$ & $\%$ IRI & $\% N$ & $\% W$ & $\% F$ & $\%$ IRI & $\% N$ & $\% W$ & $\% F$ & \%IRI \\
\hline Siphonophora & & & & & & & & & & & & & 0.07 & 0.08 & 1.85 & 0.01 \\
\hline Polychaeta & 20.43 & 31.84 & 52.38 & 35.43 & 4.90 & 14.75 & 56.76 & 9.63 & 16.89 & 12.49 & 57.14 & 18.76 & 9.29 & 8.11 & 64.81 & 11.86 \\
\hline Lumbrineris sp. & & & & & & & & & & & & & 0.14 & 0.14 & 3.70 & 0.01 \\
\hline Ostracoda & 13.30 & 1.83 & 42.86 & 8.39 & 14.40 & 3.82 & 48.65 & 7.66 & 3.53 & 0.23 & 18.37 & 0.77 & 2.98 & 0.23 & 37.04 & 1.25 \\
\hline Copepoda & 45.91 & 10.72 & 71.43 & 41.88 & 60.79 & 35.57 & 83.75 & 66.53 & 14.99 & 2.14 & 65.31 & 10.93 & 13.49 & 1.96 & 74.07 & 11.46 \\
\hline Calanoida & 0.07 & 0.01 & 2.38 & 0.01 & 1.50 & 0.15 & 37.84 & 0.54 & 0.25 & 0.01 & 2.04 & 0.01 & 0.14 & 0.01 & 1.85 & 0.01 \\
\hline Nannocalanus minor & & & & & & & & & 0.13 & 0.01 & 2.04 & 0.01 & 0.20 & 0.03 & 5.56 & 0.01 \\
\hline Pseudodiaptomus sp. & 0.15 & 0.08 & 2.38 & 0.01 & 1.12 & 1.19 & 16.22 & 0.32 & & & & & & & & \\
\hline Temora stylifera & 34.92 & 7.36 & 35.71 & 19.54 & 0.04 & 0.02 & 2.70 & 0.01 & & & & & 0.07 & 0.01 & 1.85 & 0.01 \\
\hline Centropages typicus & 0.07 & 0.01 & 2.38 & 0.01 & 0.04 & 0.01 & 2.70 & 0.01 & & & & & 0.07 & 0.01 & 1.85 & 0.01 \\
\hline Candacia armata & 0.07 & 0.04 & 2.38 & 0.01 & & & & & & & & & & & & \\
\hline Pseudocyclopia sp. & & & & & 0.04 & 0.03 & 2.70 & 0.01 & & & & & & & & \\
\hline Cyclopoida & & & & & & & & & 0.25 & 0.02 & 4.08 & 0.01 & 4.20 & 0.41 & 46.30 & 2.25 \\
\hline Corycaeus spp. & & & & & 0.17 & 0.05 & 2.70 & 0.01 & 0.15 & 0.01 & 2.04 & 0.01 & 0.20 & 0.02 & 5.56 & 0.01 \\
\hline Oncaea media & & & & & 0.09 & 0.03 & 2.70 & 0.01 & & & & & & & & \\
\hline Oncaea venusta & & & & & & & & & 0.15 & 0.03 & 2.04 & 0.01 & & & & \\
\hline $\begin{array}{l}\text { Ditrichocorycaeus } \\
\text { brehmi }\end{array}$ & 0.07 & 0.02 & 2.38 & 0.01 & & & & & & & & & & & & \\
\hline Harpacticoida & 10.48 & 3.20 & 45.24 & 8.01 & 57.78 & 34.10 & 81.08 & 64.33 & 14.13 & 2.06 & 65.31 & 11.82 & 8.61 & 1.47 & 51.85 & 5.50 \\
\hline Euterpina acutifrons & 0.07 & 0.01 & 2.38 & 0.01 & & & & & & & & & & & & \\
\hline Cirripedia larvae & 0.07 & 0.16 & 2.38 & 0.01 & & & & & 0.15 & 0.13 & 2.04 & 0.01 & 1.15 & 1.39 & 11.11 & 0.30 \\
\hline Mysidacea & 2.67 & 1.39 & 40.48 & 2.13 & 2.11 & 2.11 & 48.65 & 1.77 & 14.79 & 3.62 & 65.31 & 13.44 & 8.81 & 2.53 & 40.74 & 4.86 \\
\hline Isopoda & 0.67 & 0.21 & 11.90 & 0.14 & 0.64 & 0.39 & 16.22 & 0.15 & 4.41 & 0.67 & 32.65 & 1.85 & 1.15 & 0.20 & 18.52 & 0.26 \\
\hline Amphipoda & 3.79 & 0.96 & 50.00 & 3.07 & 0.60 & 0.29 & 27.03 & 0.21 & 10.48 & 1.26 & 59.18 & 7.76 & 25.08 & 3.52 & 77.78 & 23.39 \\
\hline Decapoda & 1.19 & 11.88 & 28.57 & 4.83 & 0.26 & 4.98 & 16.22 & 0.73 & 7.18 & 34.29 & 57.14 & 26.48 & 4.20 & 23.16 & 44.44 & 12.79 \\
\hline Tanaidacea & 7.28 & 10.68 & 35.71 & 8.30 & 3.22 & 9.13 & 62.16 & 6.63 & 4.79 & 3.35 & 14.29 & 1.30 & 1.63 & 1.34 & 12.96 & 0.40 \\
\hline Pteropoda & & & & & & & & & & & & & 0.20 & 0.02 & 1.85 & 0.01 \\
\hline Cumacea & 1.56 & 3.15 & 26.19 & 1.59 & & & & & & & & & 1.36 & 1.54 & 31.48 & 0.96 \\
\hline Brachyura la & 0.07 & 1.75 & 2.38 & 0.06 & 0.04 & 1.95 & 2.70 & 0.05 & 0.15 & 1.42 & 2.04 & 0.04 & 1.02 & 13.23 & 20.37 & 3.05 \\
\hline Gastropoda & 0.07 & 0.14 & 2.38 & 0.01 & 0.64 & 2.27 & 24.32 & 0.61 & 1.51 & 1.31 & 12.24 & 0.39 & 1.22 & 1.24 & 14.81 & 0.38 \\
\hline Bivalvia & 0.97 & 0.24 & 14.29 & 0.22 & 4.64 & 2.25 & 48.65 & 2.89 & 10.08 & 1.21 & 32.65 & 4.12 & 23.80 & 3.31 & 61.11 & 17.42 \\
\hline Chaetognatha & 0.15 & 0.01 & 4.76 & 0.01 & 0.04 & 0.01 & 2.70 & 0.01 & 0.79 & 0.01 & 4.08 & 0.04 & 0.07 & 0.01 & 1.85 & 0.01 \\
\hline Sagitta sp. & & & & & & & & & 0.92 & 0.58 & 8.16 & 0.14 & 0.07 & 0.05 & 1.85 & 0.01 \\
\hline Cladocera & & & & & & & & & & & & & & & & \\
\hline Penilia avirostris & & & & & 6.88 & 2.74 & 18.92 & 1.57 & & & & & & & & \\
\hline Stomatopoda & & & & & & & & & & & & & & & & \\
\hline Squilla mantis & 0.07 & 3.45 & 2.38 & 0.11 & 0.04 & 3.86 & 2.70 & 0.09 & & & & & 0.07 & 1.77 & 1.85 & 0.04 \\
\hline Pycnogonida & & & & & & & & & & & & & & & & \\
\hline Achelia vulgaris & & & & & & & & & & & & & 0.14 & 0.62 & 3.70 & 0.03 \\
\hline Anoplodactylus & & & & & & & & & & & & & & & & \\
\hline petiolatus & & & & & & & & & & & & & 0.27 & 0.25 & 5.56 & 0.03 \\
\hline Echinodermata & 1.26 & 11.20 & 38.10 & 6.14 & 0.60 & 10.31 & 27.03 & 2.55 & 2.40 & 10.15 & 32.65 & 4.58 & 2.03 & 10.14 & 50.00 & 6.40 \\
\hline Actinopterygii & 0.45 & 10.41 & 14.29 & 2.01 & 0.09 & 5.58 & 5.41 & 0.26 & 1.67 & 26.95 & 20.41 & 6.53 & 1.49 & 25.03 & 31.48 & 8.78 \\
\hline Actinopterygii eggs & 0.07 & 0.01 & 2.38 & 0.01 & 0.09 & 0.01 & 5.41 & 0.01 & 5.21 & 0.18 & 32.65 & 1.97 & & & & \\
\hline Algae & & & & & & & & & & & & & 0.27 & 0.13 & 1.85 & 0.01 \\
\hline
\end{tabular}

$n=$ number of stomachs examined, $\% N=$ the numerical index, $\% W=$ the gravimetric index, $\% F=$ frequency of occurrence, $\%$ IRI $=$ the index of relative importance. The values were calculated separately for the higher taxa (bold) and for individual species representing them to show their importance in the diet and not be included in the sum of the Table. 
substantially differs from our study. Age estimations of axillary seabream, $P$. acarne (18 years; $36 \mathrm{~cm} \mathrm{TL}$ ), given by Abecasis et al. (2008) are considerably higher than that of our findings. These differences are attributable to size range and the sampling gear, as the authors used longline, gillnet, and beach seine that enabled them to capture greater individuals than the trawling gear does. Beside the latter factors, uncalibrated and unvalidated otolith reading techniques can also be the culprit for different age estimation. Soykan et al. (2015) stated that the age of axillary seabream ranged from 1 to 8 years from east-central Aegean Sea. Velasco et al. (2011) aged axillary seabream from 1 to 7 years in the Atlantic and Mediterranean waters off southern Spain,
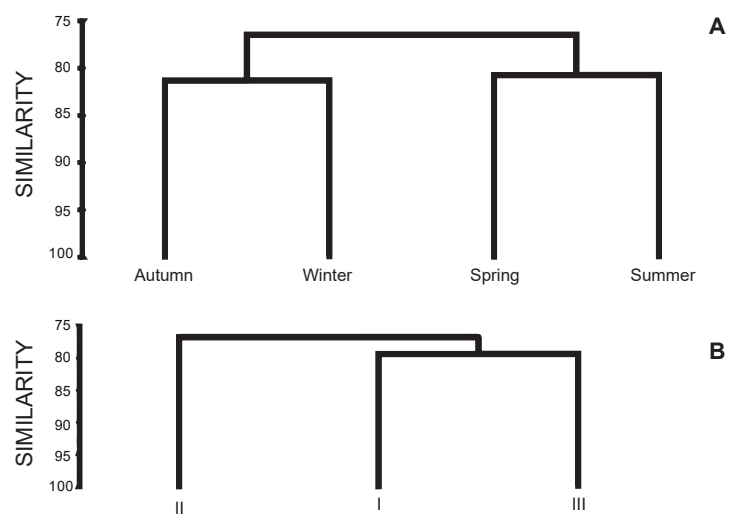

Fig. 4. Dendrogram showing seasonal (A) and size (B) similarities in stomach contents of Pagellus acarne, based on the Bray-Curtis index in the central Aegean Sea; I = length group 1; II = length group 2; III = length group 3 while Coelho et al. (2005) stated that the maximum age was 18 (only 2 individuals) and the best-represented age range was from 1 to $8(90.8 \%$ of the sample) for the southern coast of Portugal.

A comparison of the published length-weight relations and von Bertalanffy growth parameters for the species is given in Table 7. Such differences in $b$-values can be attributed to the combination of one or more of the following factors:

- Differences in the number of specimens examined

- The area or season effect

- Differences in the observed length ranges of the specimens caught (Moutopoulos and Stergiou 2002)

The values of the slope $(b)$ ranged from 2.841 to 3.499 according to localities and our results are between these values.

In the presently reported study, the asymptotic length, $25.61 \mathrm{~cm}$, is realistic since the largest specimen sampled was $22.5 \mathrm{~cm}$ long (TL). The growth coefficient $(k)$ was found to be in the mid-range of those calculated by several authors for various axillary seabream stocks inhabiting the Mediterranean Sea (Table 6). In addition, we have found that the male axillary seabream grew faster $(k=0.34)$ than the females $(k=0.21)$ as reported by Andaloro (1982), Pajuelo and Lorenzo (2000), and Coelho et al. (2005) in the northern Ionian Sea, the Canary Islands, and the southern Portugal, respectively. This is a result of the fact that axillary seabream is a protandric hermaphroditic species, which may also be evidenced by females having a lower growth rate and a larger asymptotic maximum length. A comparison of growth parameters for P. acarne is presented in Table 7 .

In addition to availability features, the presence of a food item in the diet and its selection as food (Wootton 1995) also

Table 6

Preferred prey items of axillary seabream, Pagellus acarne, determined by the principal indices

\begin{tabular}{|c|c|c|c|c|c|c|c|}
\hline \multirow{2}{*}{ MIS } & \multicolumn{4}{|c|}{ Season } & \multicolumn{3}{|c|}{ Length groups $[\mathrm{cm}]$} \\
\hline & Spring & Summer & Autumn & Winter & $<14.0$ & $14.0-18.0$ & $>18.0$ \\
\hline MIP & $\begin{array}{l}\text { IRI } \geq 1936.03 \\
\text { Copepoda } \\
\text { Polychaeta }\end{array}$ & $\begin{array}{l}\text { IRI } \geq 2237.85 \\
\text { Copepoda }\end{array}$ & $\begin{array}{l}\text { IRI } \geq 2406.11 \\
\text { Decapoda }\end{array}$ & $\begin{array}{l}\text { IRI } \geq 2725.02 \\
\text { Not found }\end{array}$ & $\begin{array}{l}\text { IRI } \geq 2235.46 \\
\text { Copepoda }\end{array}$ & $\begin{array}{l}\text { IRI } \geq 2292.07 \\
\text { Copepoda }\end{array}$ & $\begin{array}{l}\text { IRI } \geq 2470.01 \\
\text { Polychaeta }\end{array}$ \\
\hline SP & $\begin{array}{l}\text { IRI }>215.12 \\
\text { Ostracoda } \\
\text { Tanaidacea } \\
\text { Echinodermata } \\
\text { Decapoda } \\
\text { Amphipoda }\end{array}$ & $\begin{array}{l}\text { IRI }>248.65 \\
\text { Polychaeta } \\
\text { Ostracoda } \\
\text { Tanaidacea } \\
\text { Bivalvia } \\
\text { Echinodermata }\end{array}$ & $\begin{array}{l}\text { IRI }>267.35 \\
\text { Actinopterygii } \\
\text { Polychaeta } \\
\text { Mysidacea } \\
\text { Copepoda } \\
\text { Amphipoda } \\
\text { Bivalvia } \\
\text { Echinodermata }\end{array}$ & $\begin{array}{l}\text { IRI }>302.78 \\
\text { Amphipoda } \\
\text { Bivalvia } \\
\text { Decapoda } \\
\text { Polychaeta } \\
\text { Copepoda } \\
\text { Actinopterygii } \\
\text { Echinodermata } \\
\text { Mysidacea }\end{array}$ & $\begin{array}{l}\text { IRI }>248.38 \\
\text { Polychaeta } \\
\text { Amphipoda } \\
\text { Tanaidacea } \\
\text { Ostracoda } \\
\text { Actinopterygii } \\
\text { Echinodermata }\end{array}$ & $\begin{array}{l}\text { IRI }>254.67 \\
\text { Polychaeta } \\
\text { Decapoda } \\
\text { Ostracoda } \\
\text { Bivalvia } \\
\text { Amphipoda }\end{array}$ & $\begin{array}{l}\text { IRI }>254.17 \\
\text { Mysidacea } \\
\text { Actinopterygii } \\
\text { Amphipoda } \\
\text { Decapoda } \\
\text { Bivalvia } \\
\text { Copepoda } \\
\text { Echinodermata }\end{array}$ \\
\hline OP & $\begin{array}{l}\text { IRI } \leq 215.12 \\
\text { Actinopterygii } \\
\text { Mysidacea } \\
\text { Cumacea } \\
\text { Other groups }\end{array}$ & $\begin{array}{l}\text { IRI } \leq 248.45 \\
\text { Mysidacea } \\
\text { Cladocera } \\
\text { Decapoda } \\
\text { Gastropoda } \\
\text { Actinopterygii } \\
\text { Other groups }\end{array}$ & $\begin{array}{l}\text { IRI } \leq 267.35 \\
\text { Isopoda } \\
\text { Tanaidacea } \\
\text { Ostracoda } \\
\text { Other groups }\end{array}$ & $\begin{array}{l}\text { IRI } \leq 302.78 \\
\text { Brachyura } \\
\text { Ostracoda } \\
\text { Cumacea } \\
\text { Tanaidacea } \\
\text { Other groups }\end{array}$ & $\begin{array}{l}\text { IRI } \leq 248.38 \\
\text { Brachyura } \\
\text { Mysidacea } \\
\text { Bivalvia } \\
\text { Stomatopoda } \\
\text { Other groups }\end{array}$ & $\begin{array}{l}\text { IRI } \leq 254.67 \\
\text { Mysidacea } \\
\text { Brachyura } \\
\text { Cumacea } \\
\text { Gastropoda } \\
\text { Other groups }\end{array}$ & $\begin{array}{l}\text { IRI } \leq 274.44 \\
\text { Isopoda } \\
\text { Ostracoda } \\
\text { Tanaidacea } \\
\text { Other groups }\end{array}$ \\
\hline
\end{tabular}

MIS = Morato Index score, MIP = main important prey, $\mathrm{SP}=$ secondary prey, $\mathrm{OP}=$ occasional prey. 


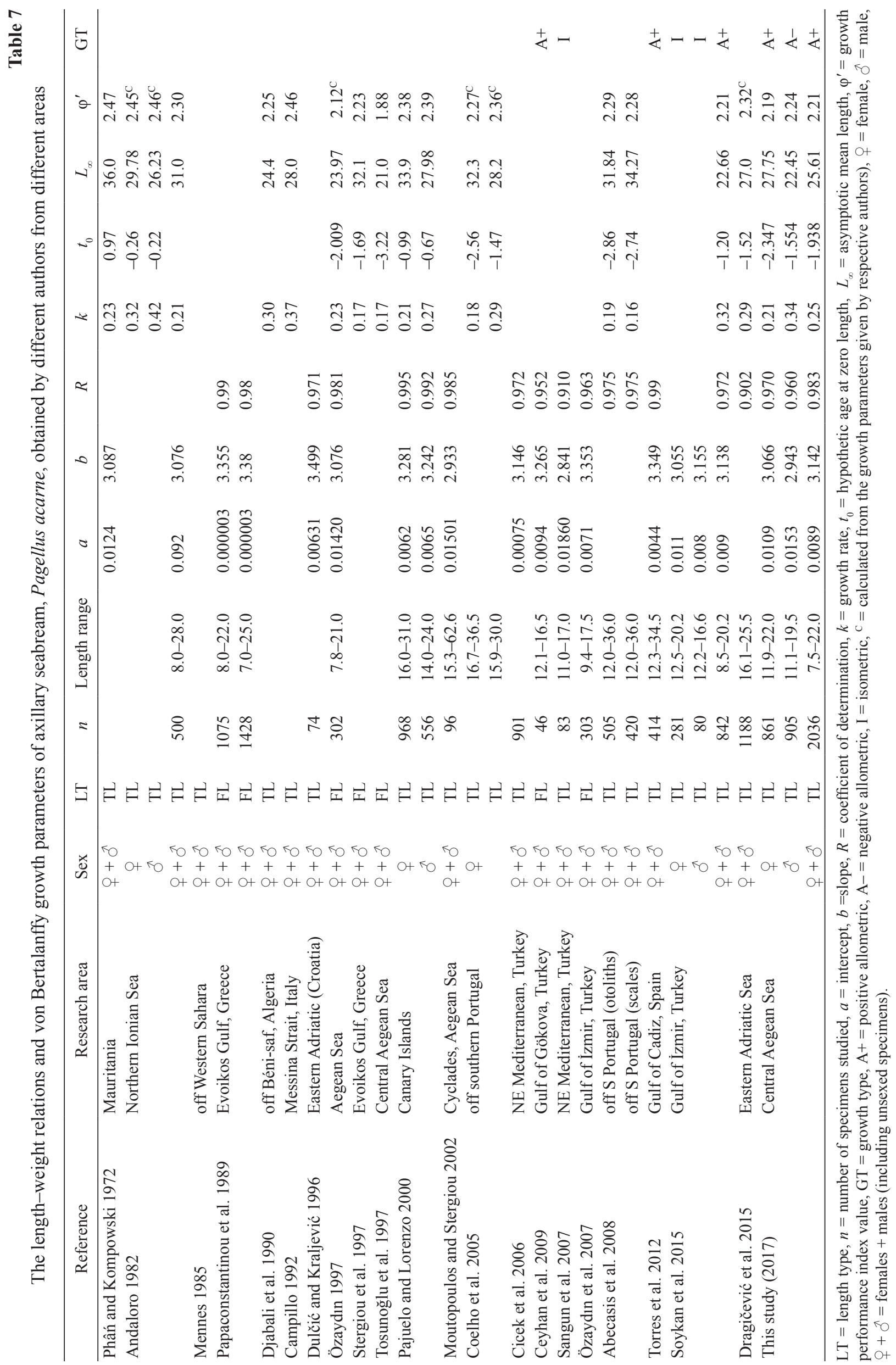


depends on the seasonal fluctuations, physical and chemical factors in sea water (Caveriviere 1990). Nikolsky (1963) revealed that the differences in the frequency of food types in the stomach are related to their frequency in the environment.

Analysing the diet of $P$. acarne from the central Aegean Sea by length groups (Table 4), harpacticoid Copepoda was found to be the most dominant food item for specimens shorter than $18 \mathrm{~cm}$, while Polychaeta was the most important one for larger individuals regardless of sex. When the diet regime is examined in terms of seasons, it was found that the primary prey item was harpacticoid Copepoda in spring and summer, Decapoda in autumn, and Amphipoda in winter regardless of size (Table 5). Considering seasons, a high number of empty stomachs was observed in summer and spring. This could be related with the metabolic activity until fixation because of a higher water temperature in these seasons.

In zooplankton abundance studies from different regions of the Aegean Sea, copepods have been reported as the most dominant group compared to other zooplanktonic groups (Pavlova 1966, Moraitou-Apostolopoulou 1985, Sever 2009). According to the stomach content analysis, axillary seabream is a carnivorous, euryphagous, and zooplanktivorous fish. Our results respect that the species feeding especially on Copepoda (Harpacticoida) at small size but in the central Aegean Sea the older ones shifted their preferences to the bigger preys like Polychaeta, Mysidacea, Amphipoda, and Decapoda. Harpacticoid copepods live in benthopelagic and benthic environments (Wells 2007). Therefore, it is apparent that $P$. acarne feed on mainly benthopelagic and benthic prey groups. In addition, it is evident that the species is an opportunist which feds on the prey groups most abundant in the environment, as indicated also by Morata et al. (2001).

Andaloro (1983) determined that the diet composition of axillary seabream consisted of Crustacea, Mollusca, Echinodermata, Annelida and Cnidaria for the Messina Strait. Another study - conducted by Domanevskaya and Patokina (1985) in the middle east Atlantic_-revealed that the dominant food items were Crustacea, Mollusca, Polychaeta, and Echinodermata. Özaydın (unpublished*) stated that the diet of the majority of $P$. acarne included Polychaeta, Mysidacea, Decapoda, and Amphipoda, throughout the Aegean Sea. However, Rizkalla et al. (1999) reported that crustaceans, teleosts, and echinoderms constituted the main food items of axillary seabream in the Egyptian Mediterranean Waters. According to Morato et al. (2001) the diet of 38 axillary seabream specimens with 21.0-28.0 cm FL from the north-eastern Atlantic, consisted of a wide variety of small organisms, mainly fishes and several invertebrates (Thaliacea and Ophiuroidea). FehriBedoui et al. (2009) identified benthic organisms such as Arthropoda, Mollusca, and Echinodermata as the dominant food items of $P$. acarne in the Gulf of Tunisia. Fanelli et al. (2011) revealed that $P$. acarne preferred suprabenthic prey in the Gulf of Castellammare (southern Tyrrhenian Sea, western Mediterranean) as well as peracarid Crustaceans in the benthic boundary layer several meters above the bottom. Dragičević et al. (2015) pointed out that axillary seabream feeds mainly on benthic invertebrates and its prey consisted mainly of crustaceans and polychaetes in the eastern Adriatic Sea.

The presently reported study provides important, fundamental information on the biology and fishery of P. acarne, which would be needed for fishery biologists and marine scientists to improve time management strategies for sustainability of its remaining stocks.

The Gulf of İzmir is a eutrophic area in terms of the aquatic resources of the Aegean Sea due to its geographical and hydrodynamic structure. Population densities of demersal species, which are the subject of many national and international studies are well known to have been noticeably decreased because of high pollution loads, overfishing, and illegal fishing activities. Due to the increasing demand on the fisheries products in recent years, the sustainable use of the aquatic living resources could only be achieved if the legal precautions could be adequately observed and the fishing effort regulated.

\section{ACKNOWLEDGEMENTS}

This study was supported by the Ege University Scientific Research Fund (Project No: 2011/SÜF/001).

\section{REFERENCES}

Abecasis D., Bentes L., Coelho R., Correia C., Lino P.G., Monteiro P., Gonçalves J.M.S., Ribeiro J., Erzini K. 2008. Ageing seabreams: A comparative study between scales and otoliths. Fisheries Research 89 (1): 37-48. DOI: 10.1016/j.fishres.2007.08.013

Andaloro F. 1982. Résumé de paramètres biologiques sur Pagellus acarne de la mer Tyrrhénienne méridionale et de la mer Ionienne septentrionale. Rapport de la première consultation technique sur l'évaluation des stocks dans la Mediterranée centrale. Tunis, 19-23 avril 1982. Conseil géneral des pêches pour la Mediterranée (CGPM). FAO, Rapport sur des pêches No 266: 89-92.

Beckman D.W., Wilson C.A. 1995. Seasonal timing of opaque zone formation in fish otoliths. Pp. 27-43. In: Secor D.H., Dean J.M., Campana S.E. (eds.) Recent developments in fish otolith research. University South Carolina Press, Columbia, SC, USA.

Campillo A. 1992. Les pêcheries françaises de Méditerranée. Synthèse des connaissances. Contrat CEE/IFREMER n* 92/1211 625/TF.

Caveriviere A. 1990. [Annexe IV] Le régime alimentaire des principales espèces demersales de Cote d'Ivoire (et du Golfe de Guinée). Pp. 125-143. Rapport du groupe de travail ad hoc sur les stocks demersaux de la région du golfe de Guinée Ouest (Division Statistique 34.3.4.). Centro Costero de Canarias, Santa Cruz de Tenerife, Espagne, 23-27 mars 1987. Programme pour le développement des pèches dans l'Atlantique centre-est. Comite des pèches pour l'Atlantique centre-est. FAO, Rome. 
Ceyhan T., Akyol O., Erdem M. 2009. Length-weight relationships of fishes from Gökova Bay, Turkey (Aegean Sea). Turkish Journal of Zoology 33 (1): 6972. DOI: 10.3906/zoo-0802-9

Cicek E., Avsar D., Yeldan H., Ozutok M. 2006. Length-weight relationships for 31 teleost fishes caught by bottom trawl net in the Babadillimani Bight (northeastern Mediterranean). Journal of Applied Ichthyology 22 (4): 290-292. DOI: 10.1111/j.14390426.2006.00755.x

Coelho R., Bentes L., Correia C., Gonçalves J.M.S., Lino P.G., Monteiro P., Ribeiro J., Erzini K. 2005. Age, growth and reproduction of the axillary seabream. Pagellus acarne (Risso, 1827), from the south coast of Portugal. Thalassas 21 (1): 79-84.

Djabali F., Boudraa S., Bouhdid A., Bousbia H., Bouchelaghem E.H., Brahmi B., Dob M., Derdiche O., Djekrir F., Kadri L., Mammasse M., Stambouli A., Tehami B. 1990. Travaux réalisés sur les stocks pélagiques et démersaux de la région de Béni-saf. FAO Fisheries and Aquaculture Report No. 447: 160-165.

Dragičević B., Dulčić J., Grgičević R. 2012. Biometric properties of axillary sea bream, Pagellus acarne (Osteichthyes: Sparidae) from the eastern Adriatic Sea. Annales, Series historia naturalis 22 (1): 71-76.

Dragičević B., Grgičević R., Stagličić N., Dulčić J., Matic-Skoko S., Tutman P., Bojanić-Varezić D., Pallaoro A. 2015. Some biological parameters of Pagellus acarne (Risso, 1827) from the eastern Adriatic Sea. Frontiers in Marine Science. Conference Abstract: XV European Congress of Ichthyology. DOI: 10.3389/conf.fmars.2015.03.00077

Domanevskaya M.V., Patokina F.A. 1985. Feeding of large-eyed dogtooth, Dentex macrophthalmus and Spanish bream, Pagellus acarne from the centraleastern Atlantic Ocean. Journal of Ichthyology 24 (5): $107-112$.

Dulčić J., Kraljević M. 1996. Weight-length relationship for 40 fish species in the eastern Adriatic (Croatian waters). Fisheries Research 28 (3): 243-251. DOI: 10.1016/0165-7836(96)00513-9

Fanelli E., Badalamenti F., D’Anna G., Pipitone C., Riginella E., Azzurro E. 2011. Food partitioning and diet temporal variation in two coexisting sparids, Pagellus erythrinus and Pagellus acarne. Journal of Fish Biology 78 (3): 869-900. DOI: 10.1111/j.10958649.2011.02915.x

Fehri-Bedoui R., Mokrani E., Ben Hassine O.K. 2009. Feeding habits of Pagellus acarne (Sparidae) in the Gulf of Tunis, central Mediterranean. Scientia Marina 73 (4): 667-678. DOI: 10.3989/scimar.2009.73n4667

Froese R., Pauly D. (eds.) 2018. FishBase. [Version 06/2018] http://www.fishbase.org

Gordoa A., Moli B. 1997. Age and growth of the sparids Diplodus vulgaris, D. sargus and D. annularis in adult populations and the differences in their juvenile growth patterns in the north-western Mediterranean Sea. Fisheries Research 33 (1-3): 123-129. DOI: 10.1016/S0165-7836(97)00074-X
Greco S., Genovese L., Micale V. 1995. Growth, gonadal histology and liver lipid composition in Pagellus acarne. Marine aquaculture finfish species diversification. CIHEAM Options Méditerranéennes No. 16: 89-101.

Green B.S., Mapstone B.D., Carlos G., Begg G.A. (eds.) 2009. Tropical fish otoliths: Information for assessment, management and ecology. Vol. 11 of Series: Reviews: Methods and Technologies in Fish Biology and Fisheries. Springer Netherlands, Amsterdam. DOI: 10.1007/978-1-4020-5775-5

Hilborn R., Walters C.J. (eds.) 1992. Quantitative fisheries stock assessment: Choice, dynamics and uncertainty. Springer US, New York, NY, USA. DOI: 10.1007/978-1-4615-3598-0

Hyslop E.J. 1980. Stomach content analysis - a review of methods and their application. . Journal of Fish Biology 17 (4): 411-429. DOI: 10.1111/j.10958649.1980.tb02775.x

Mennes F. 1985. Multi species assessment of fish stocks off the Western Sahara region with emphasis on the family Sparidae. Fishbyte 3 (3): 5-10.

Moraitou-Apostolopoulou M. 1985. The zooplankton communities of the eastern Mediterranean (Levantine Basin, Aegean Sea); Influence of man-made factors. Pp. 303-329. DOI: 10.1007/978-1-4899-2248-9 14 In: Moraitou-Apostolopoulou M., Kiortsis V. (eds.) Mediterranean marine Ecosystems. NATO Conference Series Vol. 8. DOI: 10.1007/978-1-4899-2248-9

Morato T., Solà E., Grós M.P., Menezes G. 2001. Feeding habits of two congener species of seabreams, Pagellus bogaraveo and Pagellus acarne, off the Azores (northeastern Atlantic) during spring of 1996 and 1997. Bulletin of Marine Science 69 (3): 1073 1087.

Moutopoulos D.K., Stergiou K.I. 2002. Length-weight and length-length relationships of fish species from the Aegean Sea (Greece). Journal of Applied Ichthyology 18 (3): 200-203. DOI: 10.1046/j.14390426.2002.00281.x

Munro J.L., Pauly D. 1983. A simple method for comparing growth of fishes and invertebrates. Fishbyte 1 (1): 5-6.

Nikolsky G.V. 1963. The ecology of fishes. Academic Press, London, UK.

Özaydın O., Uçkun D., Akalın S., Leblebici S., Tosunoğlu Z. 2007. Length-weight relationships of fishes captured from İzmir Bay, central Aegean Sea. Journal of Applied Ichthyology 23 (6): 695-696. DOI: 10.1111/j.1439-0426.2007.00853.x

Papaconstantinou C., Petrakis G., Mytilineou Ch., Politou Ch., Vassilopoulou V., Fourtouni A. 1989. Alieftikī erevna tōn venthopelagikōn psariōn tou Evvoïkou kai Pagasītikou kólpou. [Fisheries research of the demersal fishes of Evvoikos and Pagasitikos Gulfs.] Ethnikó Kentro Thalassion Ereynōn. [National Centre for Marine Research.] Athens, Greece. [In Greek.] 
Pajuelo J.G., Lorenzo J.M. 2000. Reproduction, age, growth and mortality of axillary seabream, Pagellus acarne (Sparidae) from the Canarian Archipelago. Journal of Applied Ichthyology 16 (2): 41-47. DOI: 10.1046/j.1439-0426.2000.00154.x

Pavlova E.V. 1966. Sostav i raspredelenie zooplanktona $\mathrm{V}$ Ėgejskom More. [Composition and distribution of zooplankton in the Aegean Sea.] Pp. 38-61. In: Vodânickij V.A. (ed.) Issledovaniâ planktona ûžnyh morej. [Investigation of plankton in South Seas.] Nauka, Moskva, USSR.

Phân L.-T., Kompowski A. 1972. The bronze breamPagellus acarne (Risso) from the north-west African region. Acta Ichthyologica et Piscatoria 2 (1): 3-18. DOI: 10.3750/AIP1972.02.1.01

Pinkas L.M., Oliphant S., Iverson I.L.K. 1971. Food habits of albacore, bluefin tuna, and bonito in California waters. Fish Bulletin 152: 1-105.

Ricker W.E. 1975. Computation and interpretation of biological statistics of fish populations. Bulletin of the Fisheries Research Board of Canada No. 191.

Rizkalla S.I., Wadie W.F., El-Zahaby A.S., El-Serafy S.S. 1999. Feeding habits of sea breams (genus: Pagellus) in the Egyptian Mediterranean waters. Journal of King Abdulaziz University, Marine Science 10: $125-140$.

Rose M. 1933. Copépodes pélagiques. Faune de France. Vol. 26. Fédération Française des sociétés de sciences naturelles; office central de faunistique. Paul Lechevalier, Paris, France.

Russell B., Carpenter K.E., Pollard D. 2014. Pagellus acarne. The IUCN Red List of Threatened Species 2014. e.T170229A1297432. DOI: 10.2305/IUCN. UK.2014-3.RLTS.T170229A1297432.en

Sangun L., Akamca E., Akar M. 2007. Weight-length relationships for 39 fish species from the north-eastern Mediterranean coast of Turkey. Turkish Journal of Fisheries and Aquatic Science 7 (1): 37-40.

Santos M.M., Montero C.C., Erzini K. 1995. Aspects of the biology and gillnet selectivity of the axillary seabream (Pagellus acarne, Risso) and common pandora (Pagellus erythrinus, Linnaeus) from the Algarve (south Portugal). Fisheries Research 23 (3-4): 223-236. DOI: 10.1016/0165-7836(94)00354-Y

Sever T.M. 2009. Ege Denizi pelajik kopepod faunası ve yaygın türlerin dağılımları. [Pelagic copepod fauna of the Aegean Sea and the distribution of the common species.] Ege University Journal of Fisheries and Aquatic Sciences 26 (3): 203-209. [In Turkish.]
Soykan O., İlkyaz A.T., Metin G., Kınacıgil H.T. 2015. Growth and reproduction of Boops boops, Dentex macrophthalmus, Diplodus vulgaris, and Pagellus acarne (Actinopterygii: Perciformes: Sparidae) from east-central Aegean Sea, Turkey. Acta Ichthyologica et Piscatoria 45 (1): 39-55. DOI: 10.3750/ AIP2015.45.1.05

Sparre P., Venema S.C. 1992. Introduction to tropical fish stock assessment. Part 1. Manual. FAO Fisheries Technical Paper No. 306/1, Rev.1, FAO, Rome.

Stergiou K.I., Christou E.D., Georgopoulous D., Zenetos A., Souvermezoglou C. 1997. The Hellenic seas: Physics chemistry, biology and fisheries. Pp. 415-538. In: Ansell A.D., Gibson R.N., Barnes M. (eds.) Oceanography and marine biology-An annual review Vol. 35. UCL Press, London, UK.

Taylor C.C. 1958. Cod growth and temperature. Journal du Conseil International pour l'Exploration de la Mer 23: $366-370$.

Tosunoğlu Z., Akyol O., Metin G., Tokaç A., Ünsal S. 1997. Gülbahçe Körfezi'ndeki üç sparid türünün populasyon özeliklerinin araştırılması. [The study on the population characteristics of three sparid species in the Gülbahçe Bay.] Ege University Journal of Fisheries and Aquatic Sciences 14 (1-2): 127-143. [In Turkish.]

Torres M.A., Ramos F., Sobrino I. 2012. Length-weight relationships of 76 fish species from the Gulf of Cadiz (SW Spain). Fisheries Research 127-128: 171-175. DOI: 10.1016/j.fishres.2012.02.001

Velasco E.M., Jiménez-Tenorio N., Del Arbol J., Bruzón M.A., Baro J., Sobrino I. 2011. Age, growth and reproduction of the axillary seabream, Pagellus acarne, in the Atlantic and Mediterranean waters off southern Spain. Journal of the Marine Biological Association of the United Kingdom 91 (6): 1243 1253. DOI: $10.1017 / \mathrm{S} 0025315410000305$

Washington H.G. 1984. Diversity, biotic and similarity indices: A review with special reference to aquatic ecosystems. Water Research 18 (6): 653-694. DOI: 10.1016/0043-1354(84)90164-7

Wells J.B.J. 2007. An annotated checklist and keys to the species of Copepoda Harpacticoida (Crustacea). Zootaxa 1568: 1-872.

Wootton R.J. 1995. Ecology of teleost fishes. Chapman and Hall, London, UK.

Received: 30 April 2018

Accepted: 2 October 2018

Published electronically: 31 December 2018 